\title{
Proliferation of Pseudo-nitzschia brasiliana and $P$. cf. pseudodelicatissima (Bacillariophyceae) in the Estero Santa Cruz, northern Gulf of California, Mexico
}

\author{
Proliferación de Pseudo-nitzschia brasiliana y P. cf. pseudodelicatissima (Bacillariophyceae) \\ en el Estero Santa Cruz, norte del Golfo de California, México

\section{Ismael Gárate-Lizárraga ${ }^{1}$, Carlos Antonio Poot-Delgado ${ }^{2,3}$, Erick Ramsés Ramírez-Castillo ${ }^{4}$ and Manuel Humberto Páez-Hernández ${ }^{5}$}

\begin{abstract}
${ }^{1}$ Instituto Politécnico Nacional, Centro Interdisciplinario de Ciencias Marinas, Departamento de Plancton y Ecología Marina, Avenida Instituto Politécnico Nacional s/n, Col. Playa Palo de Santa Rita, La Paz, Baja California Sur 23096, México. igarate@ipn.mx

${ }^{2}$ Centro de Estudios del Mar, Departamento de Recursos Acuáticos, Km. 1 Carretera Campeche-Hampolol s/n, Col. Palmas, Campeche, Campeche 24027, México

${ }^{3}$ Laboratorio de Botánica Marina y Planctología, Instituto de Ciencias Marinas y Pesquerías, Universidad Veracruzana, Calle Hidalgo № 617, Col. Rio Jamapa, Boca del Rio. Veracruz, C.P. 94290, México

${ }^{4}$ Comité de Sanidad Acuícola del Estado de Sonora, Ébanos № 58, Col. Fuentes del Mezquital, Hermosillo, Sonora, México ${ }^{5}$ Dirección General de Protección contra Riesgos Sanitarios del Estado de Sonora, Paseo del Canal y Comonfort, Edificio Sonora, Sonora, México
\end{abstract}

\begin{abstract}
A moderate bloom of Pseudo-nitzschia species occurred during collection of phytoplankton in Estero Santa Cruz, the State of Sonora, Mexico, in August 2012. The abundance of Pseudo-nitzschia in 2 samples was $84 \times 10^{3}$ and $160 \times 10^{6}$ cells $\mathrm{L}^{-1}$. Results show the presence of 2 species, $P$. brasiliana and $P$. cf. pseudodelicatissima, which were responsible for a microalgae bloom. This is the first proliferation of $P$. brasiliana in the Gulf of California. $P$. cf. pseudodelicatissima was present in higher densities. A short morphological description is provided, including data from scanning electronic microscopy.
\end{abstract}

Key words: Diatom blooms, Pseudo-nitzschia brasiliana, P. cf. pseudodelicatissima, oyster farming, Gulf of California, Mexico

\section{INTRODUCTION}

Microalgae blooms are common natural phenomena along the both coasts of the Gulf of California (CortésAltamirano \& Núñez-Pasten 1992, Alonso-Rodríguez \& Ochoa 2004, Martínez-López et al. 2006, 2008; GárateLizárraga et al. 2007, 2009). These blooms include dinoflagellates, diatoms, raphidophytes, cyanobacteria, silicoflagellates and ciliates (Cortés-Altamirano \& NúñezPasten 1992, Gárate-Lizárraga et al. 2002, Band-Schmidt et al. 2005, Gárate-Lizárraga \& Muñetón-Gómez 2008, Gárate-Lizárraga \& Muciño-Márquez 2012). Dinoflagellates and diatoms are responsible for most of the blooms in the Gulf of California (Gárate-Lizárraga et al. 2001, 2006, Alonso-Rodríguez \& Ochoa 2004). Species of diatoms, such as Chaetoceros curvisetus Cleve, C. debilis Cleve, C. radicans F. Schütt, C. socialis H.S. Lauder, Cylindrotheca closterium (Ehrenberg) Reimann \& J.C. Lewin, Eucampia zodiacus Ehrenberg, Nitzschia sigma (Kützing) W. Smith, Pseudo-nitzschia spp., Rhizosolenia debyana H. Peragallo, Stephanopyxis palmeriana (Greville) Grunow, and Thalassiosira spp. have proliferated in the Gulf of California (Gárate-Lizárraga et al. 1990, 2001, 2003, 2006, Cortés-Altamirano \& NúnezPasten 1992, Gárate-Lizárraga \& Muñetón-Gómez 2009, Molina et al. 1997).

The potentially toxic diatom genus Pseudo-nitzschia is a common component of the microalgal assemblage in the Gulf of California (Gárate-Lizárraga et al. 1990, Moreno et al. 1996). Pseudo-nitzschia blooms in the study region are related to upwelling events (Gárate-Lizárraga et al. 2007). At present, 7 species of Pseudo-nitzschia have been identified in the Gulf of California: P. americana (Hasle) Fryxell, P. australis Frenguelli, P. brasiliana N. Lundholm, G.R. Hasle \& G.A. Fryxell, P. fraudulenta (Cleve) Hasle, P. pseudodelicatissima (Hasle) Hasle, $P$. pungens (Grunow ex Cleve) Hasle, and $P$. subfraudulenta (G.R. Hasle) G.R. Hasle (Hernández-Becerril 1998, Lundholm et al. 2002, Sierra-Beltrán et al. 2005, GárateLizárraga et al. 2007). Blooms of Pseudo-nitzschia have been scarcely reported in the Gulf of California (Sierra- 
Beltrán et al. 1997, 2005, Cortés-Altamirano \& LiceaDurán 2004, Gómez-Aguirre et al. 2004, Gárate-Lizárraga et al. 2007, Ayala-Rodríguez 2008). This report describes the first proliferation of the potentially toxic diatoms Pseudonitzschia brasiliana and $P$. cf. pseudodelicatissima in the Estero Santa Cruz, Mexico (August 2012), including a brief description of both taxa.

\section{Materials AND METHODS}

The Estero Santa Cruz lies between the delta region of the Rio Colorado and the extensive mudflats of Ensenada Pabellones and Bahía Santa María, Sinaloa, approximately 1,000 km south of the Delta (Meling-López et al. 1998, Fleischner \& Gates 2009). Estero Santa Cruz is a mediumsized lagoon south of the town of Bahía de Kino. Its 3,622 ha area contains salt marshes, mangroves, and sand/mud flats, as well as permanent channels up to $3 \mathrm{~m}$ in depth (Fleischner \& Gates 2009). Since the damming of the Río Sonora in 1947, Estero Santa Cruz no longer receives freshwater. The estuary-turned-lagoon is hypersaline (Quevedo-Estrada 2007). This aquatic system is now developing into a region of aquaculture ponds for oyster farming and shrimp cultivation.

As part of a monitoring program, phytoplankton bottle samples were collected on 1 August 2012 at 2 sampling stations in the northern part of the lagoon (Station 1: $28^{\circ} 47^{\prime} 37.88^{\prime \prime} \mathrm{N}, 111^{\circ} 54^{\prime} 43.22^{\prime \prime} \mathrm{W}$ and Station 2: $28^{\circ} 48^{\prime} 0.35^{\prime}$ 'N, $111^{\circ} 55^{\prime} 1.56^{\prime \prime} \mathrm{W}$ ) where oysters are cultivated (Fig. 1). Phytoplankton surface samples for species identification and counting were collected with plastic flasks. Surface vertical tows were made with a hand net ( $50 \mathrm{~cm}$ in diameter, $20 \mu \mathrm{m}$ mesh size). A portion of each tow was immediately fixed with Lugol's acid solution. Temperature, salinity, and $\mathrm{pH}$ were recorded with a calibrated multi-parameter sampler (HI9828) at each sampling station. Cells were counted in $10 \mathrm{~mL}$ sedimentation chambers under an inverted microscope (Axio Observer, Carl Zeiss, Oberkochen, Germany; Hasle 1978). Primary identification was made up to the genus level and further some specimens were examined by scanning electron microscopy (JEOL JSM-5600 SEM, Peabody, Mass.). Samples were prepared for SEM as described in Kaczmarska et al. (2005). Preparation and observation was done at the Digital Microscopy Facility, Mount Allison University, Canada. In each sample, specimens identified as Pseudo-nitzschia spp. were examined for morphometric characteristics (width and length of the valve, density of striae, fibulae and poroids under SEM).

\section{Results AND DISCUSSION}

Sea surface temperature during the bloom varied from 32.5 to $34^{\circ} \mathrm{C}$. Salinity ranged from 34 to 37 , and the $\mathrm{pH}$ ranged from 7.6-7.7. The species list and abundances are compiled in Table 1. Total phytoplankton abundance at Station 1 was $556 \times 10^{3}$ cells L ${ }^{-1}$ and $618 \times 10^{3}$ cells L ${ }^{-1}$ at Station 2. Nanoflagellates were numerically the most important group, followed by diatoms and dinoflagellates (Table 1). Among diatoms, abundance of Pseudonitzschia in the 2 samples was $84 \times 10^{3}$ at Station 2 and

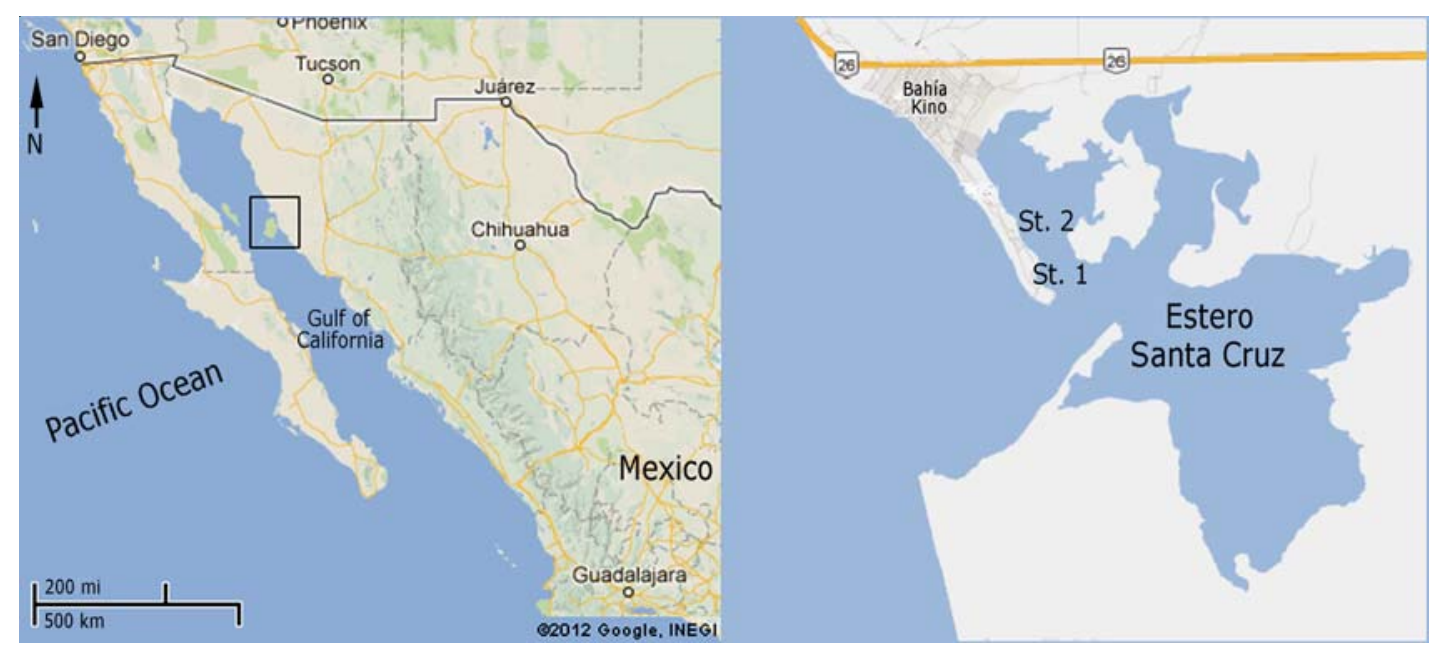

Figure 1. Location of Estero Santa Cruz ( $\left.28^{\circ} 48^{\prime} \mathrm{N}, 111^{\circ} 55^{\prime} \mathrm{W}\right)$, and sampling sites adjacent to Bahía Kino, Sonora, Mexico in August 2012 / Localización del Estero Santa Cruz $\left(\sim 28^{\circ} 48^{\prime} \mathrm{N}, 111^{\circ} 55^{\prime} \mathrm{W}\right)$, y los sitios de muestreos adyacentes a Bahía Kino, Sonora, México en agosto de 2012 
Table 1. Abundance of microalgae species recorded in the Estero Santa Cruz, Bahía Kino, Sonora during the proliferation of Pseudo-nitzschia spp. in August 2012 / Abundancia de las especies de microalgas registradas en el Estero Santa Cruz, Bahía Kino, Sonora durante la proliferación de Pseudo-nitzschia spp. en agosto de 2012.

\begin{tabular}{|c|c|c|}
\hline \multirow[t]{2}{*}{ Species composition } & \multicolumn{2}{|c|}{ Sampling station (cells $\mathrm{L}^{-1}$ ) } \\
\hline & 1 & 2 \\
\hline \multicolumn{3}{|l|}{ Diatoms } \\
\hline Bacteriastrum sp. & 100 & 100 \\
\hline Chaetoceros spp. & 29300 & 30700 \\
\hline Chaetoceros peruviamus Brightwell & 1600 & 1000 \\
\hline Cylindrotheca closterium (Ehrenberg) Reimann \& J.C.Lewin & 22700 & 27000 \\
\hline Eucampia zodiacus Ehrenberg & 100 & 0 \\
\hline Guinardia striata (Stolterfoth) Hasle in Hasle \& Syvertsen & 6000 & 8200 \\
\hline Pseudo-nitzschia brasiliana N. Lundholm, G.R.Hasle \& G.A.Fryxell & 68200 & 33700 \\
\hline Pseudo-nitzschia cf. pseudodelicatissima (Hasle) Hasle & 92700 & 50400 \\
\hline Navicula spp. & 600 & 0 \\
\hline Rhizosolenia setigera Brightwell & 27300 & 16000 \\
\hline Rhizosolenia spp. & 500 & 600 \\
\hline Centric unidentified diatoms & 3600 & 4700 \\
\hline Pennate unidentified diatoms & 6200 & 8600 \\
\hline Total abundance of diatoms & 258900 & 181000 \\
\hline \multicolumn{3}{|l|}{ Dinoflagellates } \\
\hline Tripos furca (Ehrenberg) F. Gómez, & 0 & 100 \\
\hline Prorocentrum micans Ehrenberg & 200 & 100 \\
\hline Prorocentrum minimum (Pavillard) J.Schiller & 100 & 0 \\
\hline Peridinium quinquecorne Abé & 0 & 300 \\
\hline Protoperidinium spp. & 400 & 300 \\
\hline Naked dinoflagellates $>20 \mathrm{um}$ & 700 & 0 \\
\hline Naked dinoflagellates $<20 \mathrm{um}$ & 1100 & 1600 \\
\hline Total abundance of dinoflagellates & 2500 & 2400 \\
\hline Nanoflagellates & 295200 & 435000 \\
\hline Total phytoplankton abundance & 556600 & 618400 \\
\hline
\end{tabular}

$160 \times 10^{3}$ cells $\mathrm{L}^{-1}$ at Station 1 , respectively. Scanning electronic microscopy showed 2 species: $P$. brasiliana, with abundances varying in the 2 sampling stations from $33 \times 10^{3}$ to $68 \times 10^{3}$ cells $\mathrm{L}^{-1}$, respectively, and $P$. cf. pseudodelicatissima, with abundances varying in the 2 sampling stations from $50 \times 10^{3}$ to $92 \times 10^{3}$ cells $\mathrm{L}^{-1}$, respectively.

Pseudo-nitzschia brasiliana N. Lundholm, G.R. Hasle \& G.A. Fryxell. SEM examination showed that this species has linear frustules in girdle view, rectangular shape in valve view, with widely rounded ends (Fig. 2 a-b) and lacks a central nodule (Fig. 2 c). P. brasiliana was mainly observed as single cells or forming chains of 2 or 3 cells. Morphological measurements are: 36.4-40.1 $\mu \mathrm{m}$ long, 2.07-
$2.25 \mu \mathrm{m}$ wide; $23-26$ striae in $10 \mu \mathrm{m}$, and 22-26 fibulae in 10 $\mu \mathrm{m}, 7-9$ poroids in $1 \mu \mathrm{m}$. The species morphometric data coincided with the original description and literature (Lundholm et al. 2002, Quijano-Scheggia et al. 2011, Sahraoui et al. 2011, and Parsons et al. 2012). P. brasiliana was first described in Brazil by Lundholm et al. (2002) and has also been reported in other warm water regions, such as the Gulf of Panama, Gulf of Mexico, central Mexican coast along the Pacific; Brazil, Indonesia, Malaysia, Thailand, South Korea, Tunisia, and Vietnam (Lundholm et al. 2002, Villac et al. 2005, Lim et al. 2010, Quijano-Scheggia et al. 2011, Sahraoui et al. 2011).

Pseudo-nitzschia cf. pseudodelicatissima (Hasle) Hasle was also identified. This species was found in both 

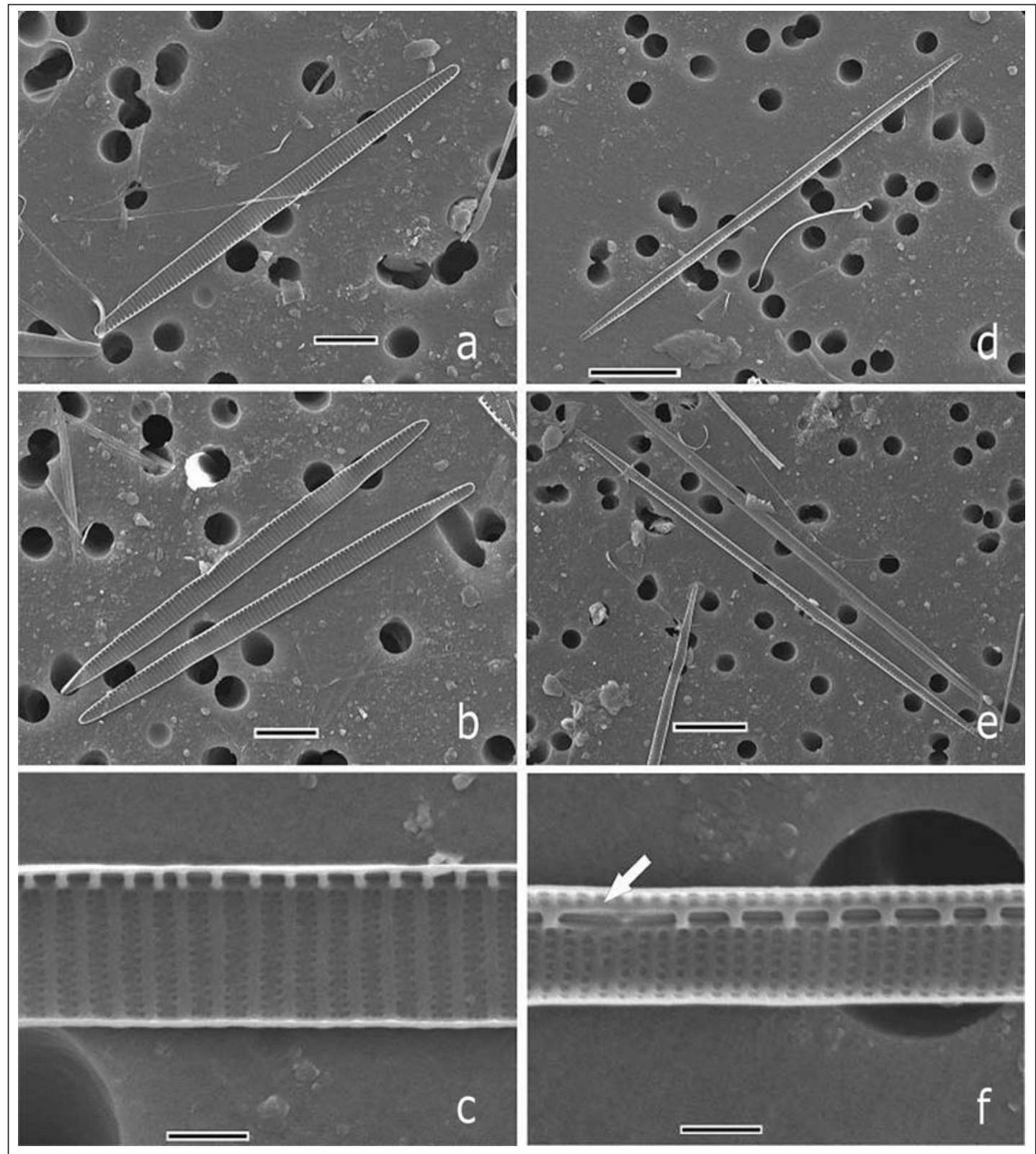

Figure 2. Scanning electron micrographs of Pseudo-nitzschia spp. collected in the Estero Santa Cruz, Bahía Kino, State of Sonora, Mexico. (ab) valves of $P$. brasiliana, scale bar $=5 \mu \mathrm{m}$; (c) central part of the valve of $P$. brasiliana showing absence of central interspace, scale bar $=1 \mu \mathrm{m}$; (d-e) valves of $P$. cf. pseudodelicatissima, scale bar $=10 \mu \mathrm{m}$; (f) $P$. cf. pseudodelicatissima central interspace, scale bar $=1 \mu \mathrm{m} / \mathrm{Imágenes} \mathrm{de}$ microscopio electrónico de Pseudo-nitzschia spp. colectadas en el Estero Santa Cruz, Bahía Kino, Sonora, México. (a-b) P. brasiliana; escala $=5 \mu \mathrm{m}$; (c) parte central de la valva de $P$. brasiliana mostrando la ausencia de interespacio central, escala de la barra $=1 \mu \mathrm{m}$; (d-e) $P$. cf. pseudodelicatissima, escala de la barra $=10 \mu \mathrm{m}$; (f) $P$. cf. pseudodelicatissima mostrando el interespacio central, escala $=1 \mu \mathrm{m}$.

samples, but it was more abundant in sample 1 (Table 1). Examination by SEM showed that this species has completely linear and symmetrical valves, terminating at rounded apices (Figs. 2 d-e). P. cf. pseudodelicatissima was observed as single cells or forming chains of 2 or 3 cells. A central, larger interspace, corresponding to 4-6 striae, was observed (Fig. 2 f). P. cf. pseudodelicatissima cells are 55.6-82.3 $\mu \mathrm{m}$ long, 1.40-1.61 $\mu \mathrm{m}$ wide; $41-42$ striae in $10 \mu \mathrm{m}, 6-7$ poroids in $1 \mu \mathrm{m}$, and $15-18$ fibulae in $10 \mu \mathrm{m}$. Cells are linear in valve view, tapering part near the tips very short. Their morphometric characteristics and measurements are consistent and within the range of $P$. 
pseudodelicatissima (Hasle \& Syvertsen, 1997, Lundholm et al. 2002, Hong-Chang et al. 2012, Parsons et al. 2012).

At least 4 different species have been described in the literature in the $P$. pseudodelicatissima/cuspidata complex: P. pseudodelicatissima, P. cuspidata (Hasle) Hasle, P. calliantha Lundholm, Moestrup \& Hasle, and $P$. caciantha Lundholm, Moestrup \& Hasle (Lundholm et al. 2003). The pseudodelicatissima/cuspidata complex is distinguished by differences in the structure of the poroid hymens and girdle bands (Lundholm et al. 2003), separating $P$. pseudodelicatissima and $P$. cuspidata from $P$. calliantha. The hymen in $P$. cuspidata and $P$. pseudodelicatissima is similar and could be distinguished between these 2 species using transmission electron microscopy. Although P. pseudodelicatissima resembles $P$. cuspidata, our specimens are most likely not $P$. cuspidata because the valves are clearly linear and not lanceolate. They are distinguished by cell width, which is relatively thin in P. pseudodelicatissima (Lundholm et al. 2003).

In previous reports, toxicity of $P$. brasiliana in several strains from by Brazil, Spain, and Malaysia were negative (Lundholm et al. 2003, Quijano-Scheggia et al. 2010); however, P. brasiliana from Bizerte Lagoon, Tunisia produces domoic acid (Sahraoui et al. 2011). Pseudonitzschia pseudodelicatissima can produce domoic acid, a causative agent of amnesic shellfish poisoning, notably some strains isolated from the Gulf of Mexico and Greece (Pan et al. 2001, Moschandreou et al. 2010). However, domoic acid has not been detected in strains of $P$. pseudodelicatissima from Gafahna, Portugal, Denmark Strait (northwest of Iceland), and Bizerte Lagoon, Tunisia (Lundholm et al. 2003, Sahraoui et al. 2011).

Given the occurrence of the potentially toxigenic diatoms $P$. brasiliana and $P$. cf. pseudodelicatissima at moderate cell densities in the Estero Santa Cruz, it appears that toxic events may occur in the future. Here we report the first proliferation of $P$. brasiliana in the Gulf of California. The first bloom of P. pseudodelicatissima was reported in Mazatlán, Sinaloa (8 July 2004). The death of ten brown pelicans (Pelecanus occidentalis californicus Ridgway), as well as several fish species were partly attributed to the Pseudo-nitzschia bloom (Sierra-Beltrán et al. 2005). In this study, we did not isolate either species of Pseudo-nitzschia to perform toxicity tests. A bloom of the 2 potentially toxic species of Pseudo-nitzschia in this lagoon system warrants a systematic and continuous monitoring program by health authorities, because commercial shellfish aquaculture sites are located there.

\section{ACKNOWLEDgMents}

We thank the Sistema Producto Ostión en Sonora, and the Instituto Politécnico Nacional (Project: SIP-20121153) for their logistical and financial support for analysis and samples collection. We gratefully thank James Ehrman (Digital Microscopy Facility, Mount Allison University, Sackville, New Brunswick, Canada) for producing the scanning electron micrographs of Pseudo-nitzschia species used in this study. We thank M. C. RamírezJáuregui (Instituto de Ciencias del Mar y Limnología, Universidad Nacional Autónoma de México) for helping us with the literature search. The authors thank the two anonymous reviewers for their helpful comments and suggestions.

\section{LITERATURE CITED}

Alonso-Rodríguez R \& JL Ochoa. 2004. Hydrology of winterspring 'red-tides' in Bahía de Mazatlán, Sinaloa, Mexico. Harmful Algae 3: 163-171.

Ayala-Rodríguez AG. 2008. Grupos funcionales del fitoplancton y estado trófico del Sistema Lagunar Topoloampo-Ohuira-Santa María. Tesis de Maestría. CICIMAR-IPN, La Paz, B.C.S., 149 pp.

Band-Schmidt CJ, A Martínez-López \& I Gárate-Lizárraga. 2005. First record of Chattonella marina in Bahía de La Paz, Gulf of California. Harmful Algae News 28: 6-7.

Cortés-Altamirano R \& S Licea-Durán. 2004. Decoloración en proliferaciones de microalgas como parámetro bioindicador en la Bahía de Mazatlán, México. Revista de Biología Tropical 52(Supl. 1): 27-34.

Cortés-Altamirano R \& A Núñez-Pasten. 1992. Doce años (1979-1990) de registros de mareas rojas en la Bahía de Mazatlán, Sinaloa, México. Anales del Instituto de Ciencias del Mar y Limnología, UNAM 19: 113-121.

Fleischner TL \& RH Gates. 2009. Shorebird use of Estero Santa Cruz, Sonora, Mexico: Abundance, diversity, and conservation implications. Waterbirds 32: 36-43.

Gárate-Lizárraga I \& RE Muciño-Márquez. 2012. Blooms of Trichodesmium erythraeum and T. thiebautii (Cyanobacteria, Oscillatoriales) in the Bahía de La Paz, Gulf of California. CICIMAR, Oceánides 27: 61-64.

Gárate-Lizárraga I \& MS Muñetón-Gómez. 2008. Bloom of Peridinium quinquecorne in la Ensenada de la Paz, Gulf of California (July 2003). Acta Botanica Mexicana 83: 3347. 
Gárate-Lizárraga I \& MS Muñetón-Gómez. 2009. Primer registro de la diatomea epibionte Pseudohimantidium pacificum y de otras asociaciones simbióticas en el Golfo de California. Acta Botanica Mexicana 88: 33-47.

Gárate-Lizárraga I, DA Siqueiros-Beltrones \& CA Lechuga-Devéze. 1990. Estructura de las asociaciones microfitoplanctónicas de la región central del Golfo de California en el otoño de 1986. Ciencias Marinas 16: 131153.

Gárate-Lizárraga I, ML Hernández-Orozco, CJ BandSchmidt \& G Serrano-Casillas. 2001. Red tides along the coasts of Baja California Sur, Mexico (1984-2001). Oceánides 16: 127-134.

Gárate-Lizárraga I, C Band-Schmidt, R Cervantes-Duarte \& DG Escobedo-Urías. 2002. Mareas rojas de Mesodinium rubrum (Lohmann) Hamburger y Budenbrock ocurridas en el Golfo de California durante el invierno de 1998. Hidrobiológica 12: 15-20.

Gárate-Lizárraga I, DA Siqueiros-Beltrones \& V Maldonado-López. 2003. First record of a Rhizosolenia debyana bloom in the Gulf of California, México. Pacific Science 57: 141-145.

Gárate-Lizárraga I, MS Muñetón-Gómez \& V MaldonadoLópez. 2006. Florecimiento del dinoflagelado Gonyaulax polygramma frente a la isla Espíritu Santo, Golfo de California, México. Revista de Investigaciones Marinas 27: 31-39.

Gárate-Lizárraga I, CJ Band-Schmidt, DJ López-Cortés \& JJ Bustillos-Guzmán. 2007. Bloom of Pseudo-nitzschia fraudulenta in Bahía de La Paz, Gulf of California (JuneJuly 2006). Harmful Algae News 33: 6-7.

Gárate-Lizárraga I, CJ Band-Schmidt, F Aguirre-Bahena \& T Grayeb-del Álamo. 2009. A multi-species microalgae bloom in Bahía de La Paz, Gulf of California, Mexico (June 2008). CICIMAR, Oceánides 24: 1-15.

Gómez-Aguirre S, S Licea-Durán \& S Gómez. 2004. Proliferaciones de Pseudo-nitzschia spp. (Bacillariophyceae) y otras especies del microplancton en la Bahía de Mazatlán, México. Revista de Biología Tropical 52(Supl. 1): 69-76.

Hasle GR. 1978. The inverted-microscope method. In: Sournia A (ed). Phytoplankton manual, pp. 88-96. UNESCO, Paris.

Hasle GR \& EE Syvertsen. 1997. Marine diatoms. In: Tomas CR (ed). Identifying marine phytoplankton pp. 1-385. Academic Press, San Diego.

Hernández-Becerril DU. 1998. Species of the planktonic diatom genus Pseudo-nitzschia of the Pacific coast of Mexico. Hydrobiologia 379: 77-84.

Hong-Chang L, L Po-Teen, SS Nyun-Pau, Y Kotaki \& L Chui-Pin. 2012. Morphological observation of two species of Pseudo-nitzschia (Bacillariophyceae) Coastal Marine Science 35: 52-57.
Kaczmarska I, JL Martin, MM LeGresley \& JM Ehrman. 2005. Diversity of the diatom genus Pseudo-nitzschia Peragallo in the Quoddy Region of the Bay of Fundy, Canada. Harmful Algae 4: 1-19

Lim HC, SNP Su, MA Hartina, Y Kotaki, CP Leaw \& PT Lim. 2010. Toxicity of diatom Pseudo-nitzschia (Bacillariophyceae) analyzed using high performance liquid chromatography (HPLC). Journal of Science and Technology in the Tropics 6: 116-119.

Lundholm N, GR Hasle, GA Fryxell \& PE Hargraves. 2002. Morphology, phylogeny and taxonomy of species within the Pseudo-nitzschia americana complex (Bacillariophyceae) with descriptions of two new species, Pseudo-nitzschia brasiliana and Pseudo-nitzschia linea. Phycologia 41: 480497.

Lundholm N, O Moestrup, GR Hasle \& K Hoef-Emden. 2003. A study of the Pseudo-nitzschia pseudodelicatissima/ cuspidata complex (Bacillariophyceae): what is $P$. pseudodelicatissima? Journal of Phycology 39: 797-813.

Martínez-López A, CJ Band-Schmidt, D Escobedo-Urías \& AE Ulloa-Pérez. 2006. Bloom of Chattonella subsalsa in an impacted coastal lagoon in the Gulf of California. Harmful Algae News 31: 4-5.

Martínez-López A, DC Escobedo-Urías, AE Ulloa-Pérez \& R Aguirre. 2008. Dynamics of a Prorocentrum minimum bloom along the northern coast of Sinaloa, México. Continental Shelf Research 28: 1693-1701.

Meling-López AE, IA Villalba-Atondo \& P Ortega-Romero. 1998. Las halófitas de la Laguna Costera La Cruz. Revista de Conservación de Suelo y Agua 1: 1-7.

Molina RE, FA Manrique \& J García. 1997. Nota sobre un florecimiento de Stephanopyxis palmeriana (Greville) Grunow (Bacillariophyceae) en la bahía Kun Kaak. Golfo de California. Hidrobiológica 7: 84-86.

Moreno JL, S Licea-Durán \& H Santoyo. 1996. Diatomeas del Golfo de California, 273 pp. Universidad Autónoma de Baja California Sur-SEPFOMES-PROMARCO, México.

Moschandreou KK, D Papaefthimiou, P Katikou, E Kalopesa, A Panou \& G Nikolaidis. 2010. Morphology, phylogeny and toxin analysis of Pseudo-nitzschia pseudodelicatissima (Bacillariophyceae) isolated from the Thermaikos Gulf, Greece. Phycologia 49: 260-273.

Pan Y, ML Parsons, M Busman, P Moeller, Q Dortch, CL Powell, GA Fryxell \& GJ Doucette. 2001. Pseudonitzschia pseudodelicatissima - a confirmed producer of domoic acid from the northern Gulf of Mexico. Marine Ecology Progress Series 220: 83-92.

Parsons ML, YB Okolodkov \& JA Aké-Castillo. 2012. Diversity and morphology of the species of Pseudonitzschia (Bacillariophyta) of the National Park Sistema Arrecifal Veracruzano, SW Gulf of Mexico. Acta Botanica Mexicana 98: 51-72. 
Quevedo-Estrada JL. 2007. Propuesta de acción para la gestión integrada en la costa de Hermosillo, Sonora. Tesis de Especialidad en Gestión Integrada de Cuencas Hidrológicas. Colegio de Sonora, Hermosillo, 42 pp. <http:// www.colson.edu.mx/Cuencas/Documents/TESINAJLQE.pdf>

Quijano-Scheggia S, E Garcés, K Andree, P de la Iglesia, J Diogène, JM Fortuño \& J Camp. 2010. Pseudo-nitzschia species in the Catalan Coast: characterization and contribution to the current knowledge of genus distribution in the Mediterranean Sea. Scientia Marina 74: 395-410.

Quijano-Scheggia S, A Olivos-Ortiz, JH GaviñoRodríguez, F Castro-Ochoa, M Rivera-Vilarelle, MA Galicia-Pérez \& M Patiño Barragán. 2011. The first report of Pseudo-nitzschia brasiliana and P. micropora (Bacillariophycea) found in Cuyutlan Lagoon, Mexico. Revista de Biología Marina y Oceanografía 46: 189-197.
Sahraoui I, SS Bates, D Bouchouicha, HH Mabrouk \& AS Hlaili. 2011. Toxicity of Pseudo-nitzschia populations from Bizerte Lagoon, Tunisia, southwest Mediterranean, and first report of domoic acid production by $P$. brasiliana. Diatom Research 26: 293-303.

Sierra-Beltrán AP, M Palafox-Uribe, J Grajales-Montiel, A Cruz-Villacorta \& JL Ochoa. 1997. Sea bird mortality at Cabo San Lucas, Mexico: evidence that toxic diatom blooms are spreading. Toxicon 35: 447-453.

Sierra-Beltrán AP, R Cortés-Altamirano, JP GalloReynoso, S Licea-Durán \& J Égido-Villarreal. 2005. Is Pseudo-nitzschia pseudodelicatissima toxin the principal cause of sardines, dolphins, sea lions and pelicans mortality in 2004 in Mexico? Harmful Algae News 29: 6-8.

Villac MC, S Melo, M Menezes \& D Rivera. 2005. Pseudonitzschia brasiliana (Bacillariophyceae), an opportunistic diatom on the coast of the state of Rio de Janeiro, Brazil. Atlântica, Río Grande 27: 139-145.

Received 5 December 2012 and accepted 10 June 2013

Associate Editor: Pilar Muñoz M. 